\title{
Pengembangan "BALING" untuk Meningkatkan Prestasi Belajar Siswa Kelas VI Sekolah Dasar
}

\author{
Erwin Winaryati Dyah Ristanti Ari Juari, ${ }^{1}$ Rida Fironika Kusumadewi², Yunita Sari ${ }^{3}$ \\ 1,2,3Universitas Islam Sultan Agung \\ email: ${ }^{1}$ erwin.winaryati12@gmail.com, \\ 2ridafkd@unissula.ac.id, 3yunitasari@unissula.ac.id
}

\begin{abstract}
This study aims to develop mathematics teaching materials on the subject of circles and to determine their feasibility and practicality. This research is motivated by the low results of student achievement, especially circle material and the lack of references used by the teacher when learning school from home (online). This teaching material can be accessed by students via smartphones and computers. This study uses the ADDIE (Analysis-Design-Development-Implementation-Evaluate) model. Based on these five stages, the development of BALING teaching materials resulted in the feasibility percentage of the three validators of $86.22 \%$ and included in the feasible criteria. The results of the teacher's response obtained a score of 48 with a percentage of $90 \%$, and the results of student responses obtained an average score of 50 with a percentage of $98 \%$ so that it is stated as practical teaching material. The average value of the students increased with the results of the gain test of 0.69 indicating that BALING teaching materials could improve student achievement in the moderate category. Based on these results, BALING teaching materials were declared feasible, practical and effective in improving the learning achievement of Grade VI students of SDN Sumbermulyo 01.
\end{abstract}

Keywords: Teaching Materials, Mathematics, Learning Achievement, Circle

Abstrak. Penelitian ini bertujuan untuk mengembangkan bahan ajar matematika pokok bahasan lingkaran serta untuk mengetahui kelayakan dan kepraktisannya. Penelitian ini dilatarbelakangi rendahnya hasil prestasi belajar siswa khususnya materi lingkaran serta kurangnya referensi yang digunakan oleh guru pada saat pembelajaran school from home (daring). Bahan ajar ini bisa diakses oleh siswa melalui smartphone dan komputer. Penelitian ini menggunakan model ADDIE (Analysisi-Design-Development-Implementation-Evaluate). Berdasarkan lima tahapan tersebut pengembangan bahan ajar BALING dihasilkan persentase kelayakan dari tiga validator sebesar $86,22 \%$ dan termasuk dalam kritria layak. Hasil respon guru memperoleh skor 48 dengan hasil persentase sebesar 90\%, dan hasil respon siswa memperoleh skor rata-rata sebesar 50 dengan hasil persentase $98 \%$ sehingga dinyatakan sebagai bahan ajar yang praktis. Nilai rata-rata siswa meningkatdengan hasil uji gain sebesar 0,69 menunjukkan bahan ajar BALING dapat meningkatkan prestasi belajar siswa dengan kategori sedang. Berdasarkan hasil tersebut bahan ajar BALING dinyatakan layak, praktis dan efektif untuk meningkatkan prestasi belajar siswa kelas VI SDN Sumbermulyo 01.

Kata Kunci: Bahan Ajar, Matematika, Prestasi Belajar, Lingkaran 


\section{PENDAHULUAN}

Pendidikan sangat berperan penting untuk meningkatkan kualitas sumber daya manusia di generasi mendatang, karena keberhasilan di dunia pendidikan sebagai faktor penentu tercapainya tujuan pendidikan yang mencerdaskan kehidupan generasi bangsa. Hal itu sangat diperlukan untuk mengikuti arus perkembangan jaman yang semakin begitu canggih dan sangat penuh dengan persaingan.Oleh karena itu, pendidikan mempunyai peranan yang sangat penting dalam mewujudkan suatu perubahan di era global ini.Terjadinya perubahan perkembangan yang lebih baik lagi merupakan tanggung jawab dari kependidikan.

Perkembangan teknologi modern tidak lepas dari peran penting ilmu Matematika.Ilmu Matematika dapat diajarkan sejak pendidikan sekolah dasar, untuk membekali mereka dalam berbagai tantangan dan pemecahan masalah dalam kehidupan sehari-hari.Mata pelajaran matematika di sekolah dasar dijadikan konsep awal tentang pemahaman matematika yang digunakan untuk jenjang yang lebih tinggi. Penalaran siswa diperoleh dari pembelajaran di sekolah dasar, sehingga dalam kehidupan seharihari mereka bisa memecahkan masalah, dapat bersikap disisplin, membuat mereka bersikap terbuka, cermat dan selalu optimis, serta dapat menghargai pembelajaran matematika (Nugroho \& Setyawati, 2016).

Pemberian materi dan tugas matematika saat daring di SD Negeri Sumbermulyo 01 biasanya melalui whatsapp grup dan google form. Hal tersebut membuat siswa menjadi kurang semangat dalam belajar, bahkan ada beberapa siswa yang tidak paham isi pembelajaran dan tugas- tugas yang disampaikan oleh guru dalam grup kelas, karena penggunaan grup kelas tersebut tidak semua siswa memperhatikan dengan seksama tugas apa dan materi apa yang diberikan oleh guru.Dampak dari hal tersebut yaitu penurunan hasil prestasi belajar 10 dari 30 siswa yang masih berada di bawah KKM. Berdasarkan pengamatan langsung di sekolah saat Magang III dan hasil wawancara kepada guru kelas VI SD Negeri yakni Bapak Juari, S.Pd.SD bahwa mayoritas siswa kelas VI menganggap bahwa pembelajaran matematika sangatlah sulit, seperti pada materi Lingkaran. Beberapa siswa kelas VI tidak mengetahui unsur-unsur yang terdapat pada lingkaran serta kurangnya kemampuan beberapa siswa dalam menyelesaikan soal yang terkait dengan keliling dan luas dari lingkaran.Bahkan ada beberapa siswa yang tidak mengetahui bagaimana rumus dalam menghitung keliling dan luas lingkaran.Penggunaan bahan ajar dalam kegiatan pembelajaran, pak Juari masih mengandalkan buku lembar kerja siswa.Maka diperlukan tambahan referensi untuk penyampaian materi lingkaran agar siswa lebih minat dan tertarik untuk belajar.Sejalan dengan penelitian (Kususmadewi, Ulia, \& Sari, 2020) mengemukakan bahwa bahan ajar yang digunakan pada SD yang diteliti masih banyak kekurangan serta bahan ajar yang digunakan masih bersifat biasa.

Berdasarkan permasalahan di atas, maka dibutuhkan tindak lanjut dalam bentuk penelitian dan pengembangan bahan ajar Matematika untuk materi Lingkaran.Sehinggapeneliti menggunakan judul yaitu "Pengembangan 'BALING' untuk Meningkatkan Prestasi Belajar Siswa Kelas VI Sekolah Dasar". 
Jurnal Riset Pendidikan Dasar

Volume 2 Nomor 2, September 2021; DOI 10.30595/jrpd.v2i2.9908

\section{METODE}

\section{Jenis Penelitian}

Jenis penelitian yang digunakan adalah R\&D (Research and Development).Menurut Sugiono (2017: 407) metode penelitian dan pengembangan adalah penggunaan metode dimana dihasilkannya suatu produk yang bermanfaat, serta menguji keefektifannya. Produk yang dikembangkan dalam penelitian ini adalah bahan ajar berbasis digital yang dapat di akses melalui smartphone kapanpun dan dimanapun.Model yang digunakan dalam pengembangan bahan ajar ini adalah model ADDIE (AnalysisiDesign-Development-ImplementationEvaluate). Model ini dikembangkan oleh Dick and Carry pada tahun 1996. Pribadi (dalam Saputra dan Faizah, 2017:68) mengemukakan bahwa ada lima tahapan utama yaitu (A)nalysis, (D)esain, (D)evelopment, (I)mplementation, dan (E)valuation.

\section{Tempat dan Waktu Penelitian}

Penelitian ini dilaksanakan di SD Negeri Sumbermulyo 01 Pati. Waktu pelaksanaan penelitian yaitu bulan Oktober tahun 2019/2020.

\section{Subjek Penelitian}

Subjek dalam penelitian ini yaitu siswa kelas VI yang berjumlah 30 siswa.

\section{Teknik Pengumpulan Data}

Teknik pengumpulan data menggunakan wawancara, angket atau kuesioner, serta tes tertulis.

\section{Instrumen Penelitian}

Instrumen pada penelitian ini adalah angket validasi bahan ajar, angket respon guru dan respon siswa serta lembar soal tertulis.

\section{Teknik Analisis Data}

Teknik analisis data yang digunakan pada penelitian ini yaitu a) Analisis kevalidan, b) Analisis data uji kepraktisan, c) Analisis uji keefektifan.

\section{HASIL DAN PEMBAHASAN}

\section{Hasil Penelitian}

Penelitian dan pengembangan ini menggunakan model pengembangan ADDIE. Model ini meliputi lima prosedur tahapan yaitu analysis, desain, development, implementation, dan evaluation(Tegeh \& Kirna, 2013).

\section{a. Analysis (Tahapan Analisis)}

1) Performance Analysis (Analisis Kinerja)

Performance analysis

(analisis kinerja) diperoleh berdasarkan hasil observasi dan wawancara dengan Bapak Juari, S.Pd.SD sebagai wali kelas VI SD Negeri Sumbermulyo 01. Hasil wawancara menyatakan adanya kesulitan siswa dalam pelaksanaan proses belajar matematika materi lingkaran. Menurunnya hasil prestasi belajar siswa merupakan dampak dari kurangnya minat belajar yang dilakukan oleh siswa pada saat daring.Nilai yang diperoleh siswa pada waktu tertentu sampai saat ini masih dijadikan acuan sebagai hasil prestasi belajar siswa (Subaryana, 2015). 
2) Need Analysis (Analisis Kebutuhan) Berdasarkan analisis kinerja, siswa kelas VI SD Negeri Sumbermulyo membutuhkan bahan ajar khususnya materi lingkaran yang bisa digunakan belajar online saat masa pandemi seperti ini.Bahan ajar adalah sesuatu yang berisi tentang ilmu, sikap yang penyusunannya secara runtut dan dipergunakan untuk mencapai tujuan pembelajaran (Sari, 2017).

\section{b. Desain (Tahapan Perancangan)}

$$
\text { Hasil tahapan analisis }
$$
digunakan sebagai sumber dalam perancangan bahan ajar. Tahapan ini dilaksanakan dengan merancang produk berupa bahan ajar yang diberi nama "BALING" untuk meningkatkan prestasi belajar siswa kelas VI pada materi lingkaran KD 3.4, 3.5, 4.4, dan 4.5 .

\section{c. Development (Tahap Pengembangan)}

Tahap pengembangan ini, terdapat beberapa hal yang dilakukan diantaranya 1) Penulisan bahan ajar, 2) Validasi bahan ajar, 3) Revisi produk, 4) Validasi instrumen tes,.

\section{d. Implementation (Tahap Penerapan)}

1) Pre-Test

Kegiatan ini dilakukan bertujuan mengukur kemampuan awal siswa kelas VI sebelum diberikan perlakuan menggunakan bahan ajar "BALING".Pre-test dilakukan pada tanggal 17 Oktober 2020. Jumlah seluruh nilai yang diperoleh pada kegiatan pre-test yaitu 1.710 dengan nilai terendah 20 yang diperoleh 4 orang siswa dan nilai tertinggi 90 yang diperoleh 6 orang siswa. Sedangkan rata-rata yang diperoleh pada hasil kegiatan pretest adalah 57 dengan nilai yang paling banyak diperoleh yaitu 90 .

2) Penggunaan Produk Pada tahap ini produk digunakan di SDN Sumbermulyo 01 kelas VI dengan jumlah siswa 30 orang.

\section{e. Evaluation (Tahap Evaluasi)}

1) Post-test

Kegiatan Post-test dilakukan dengan tujuan mengukur kemampuan siswa setelah diberikan perlakuan dengan menggunakan "BALING". Jumlah nilai Post-test dari keseluruhan siswa yaitu 2.610 dengan nilai terendah 70 yang diperoleh tiga orang siswa, serta nilai tertinggi 100 yang diperoleh lima orang siswa. Rata-rata yang diperoleh dari kegiatan Post-test yaitu 87 dengan nilai terbanyak adalah 90 .

2) Evaluasi oleh Guru

Guru yang memberikan evaluasi yaitu wali kelas VI Bapak Juari, S.Pd.SD. Evaluasi dilakukan dengan mengisi lembar angket respon guru terhadap bahan ajar "BALING" pada tanggal 2 November 2020. Hasil dari angket respon guru diperoleh skor 48 dari 50 skor maksimal, dan hasil persentase yaitu 96\% dengan kategori 'praktis'. 
3) Evaluasi oleh Siswa

Evaluasi oleh siswa dilakukan dengan cara mengisi angket respon siswa terhadap bahan ajar "BALING" yang terdiri dari 10 pernyataan. Siswa yang memberikan evaluasi merupakan siswa kelas VI SD Negeri Sumbermulyo 01. Hasil dari angket respon siswa terhadap bahan ajar diperoleh skor 1507 dengan rata-rata 50,23 dan memperoleh persentase sebesar $97,2 \%$ dengan kategori 'praktis'.

\section{Pembahasan Penelitian}

a. Kelayakan Bahan Ajar

Penyusunan bahan ajar berdasarkan beberapa referensi yang digunakan, materi dari tingkat yang mudah menuju tingkat sulit, dan penampilan bahan ajar yang menarik sehingga layak untuk digunakan.Penilaian kelayakan bahan ajar "BALING" dilakukan melalui uji validasi oleh tiga validator. Penilaian tersebut dengan cara mengisi lembar angket penilaian bahan ajar yang terdiri dari 15 pernyataan dengan 5 kriteria pilihan jawaban. Penilaian kelayakan bahan ajar didasarkan oleh tiga aspek yaitu aspek materi, aspek penyajian, dan aspek bahasaPrastowo \& Wijaya (2012:174). Bahan ajar perlu dipersiapkan dengan baik, karena mengingat betapa pentingnya fungsi sebuah bahan ajar yang akan dipergunakan dalam proses pembelajaran, senada dengan pendapat Ulia, dkk. (2020:3) yang menyatakan "bahan ajar berperan penting sehingga harus dipersiapkan agar tujuan dari pelaksanaan pembelajaran dapat tercapai sesuai yang diharapkan".

Hasil dari validasi aspek materi memperoleh persentase sebesar 90,47\% dengan kategori 'layak'. Aspek penyajian mendapatkan hasil persentase sebesar $77 \%$ dengan kategori 'layak'.Selanjutnya aspek bahasa memperoleh hasil persentase sebesar 85\% dengan kategori 'layak'.

Dari hasil uji validasi oleh ketiga validator menunjukkan bahwa bahan ajar BALING 'layak' untuk digunakan. Hasil dari validasi ketiga validator dapat dilihat pada grafik dibawah ini:

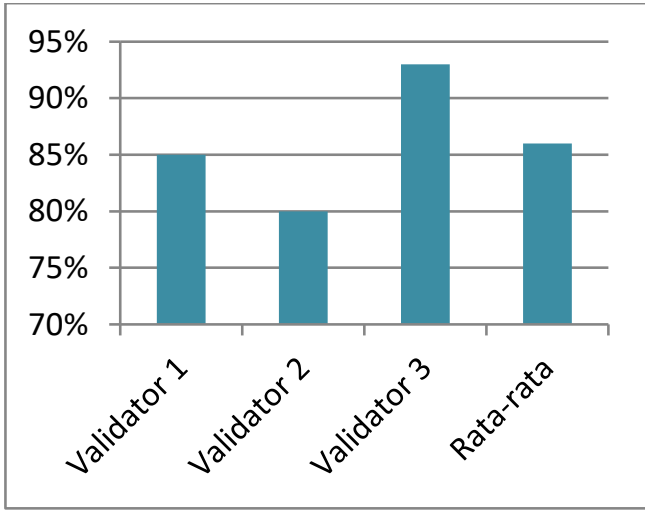

Gambar 1. Garafik Kelayakan Bahan Ajar

Uji validasi juga pernah dilakukan pada penelitian sebelunmnya yaitu pada penelitian yang dilakukan oleh (Jazuli, Azizah, \& Meita, 2017) pengembangan bahan ajar berbasis $e$ learningmemperoleh hasil lebih dari $90 \%$ sehingga bahan ajar dikategorigan sangat baik dan layak digunakan dalam proses pembelajaran. 
b. Kepraktisan Bahan Ajar

Hasil pengisian angket respon guru dan respon siswa, bahan ajar yang dikembangkan dikategorikan sebagai bahan 'praktis' dengan perolehan skor dari respon guru sebesar 48 dengan hasilpersentase sebesar 96\%. Pengisian lembar angket respon siswa memperoleh skor 1507 dengan rata-rata 50,23 dan hasil persentase sebesar $97,2 \%$.

Hasil persentase respon guru dan respon siswa terhadap penggunaan bahan ajar disajikan pada grafik berikut:

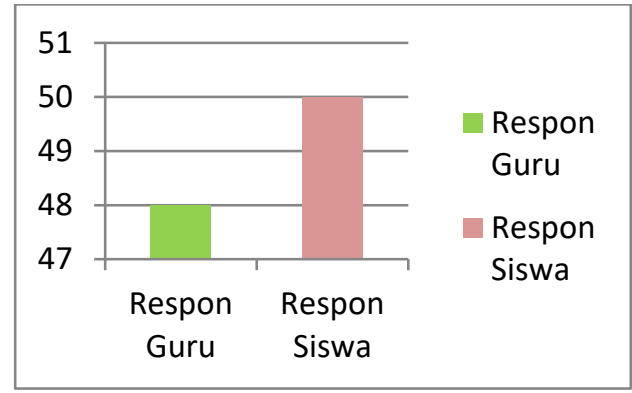

\section{Gambar 2. Grafik Hasil Uji Kepraktisan}

c. Keefektifan Bahan Ajar

Selama menggunakan buku, siswa memahami materi yang disajikan melalui penyajian contoh soal beserta pembahasannya.Siswa juga mengerjakan latihan soal dengan baik, yang mana latihan soal tersebut berkaitan dengan materi yang diajarkan.Selain itu, pada saat penggunaan bahan ajar siswa mengalami kendala berupa tidak semua handphone yang digunakan memiliki aplikasi pendukung untuk membuka file bahan ajar berupa $p d f$. Pada penelitian ini, pencapaian hasil post-test yang menunjukkan bahwa prestasi belajar siswa meningkat jika dibandingkan dengan hasil pre-test. Hal tersebut membuktikan bahwa bahan ajar dikategorikan sebagai bahan ajar yang efektif meningkatkan prestasi belajar siswa pada materi lingkaran meskipun dalam kriteria sedang.

Jumlah nilai siswa meningkat dari pre-test yaitu sebesar 1.710 meningkat menjadi 2.610 pada jumlah nilai post-test. Peningkatan prestasi belajar siswa pada materi lingkaran dapa dilihat pada grafik berikut:

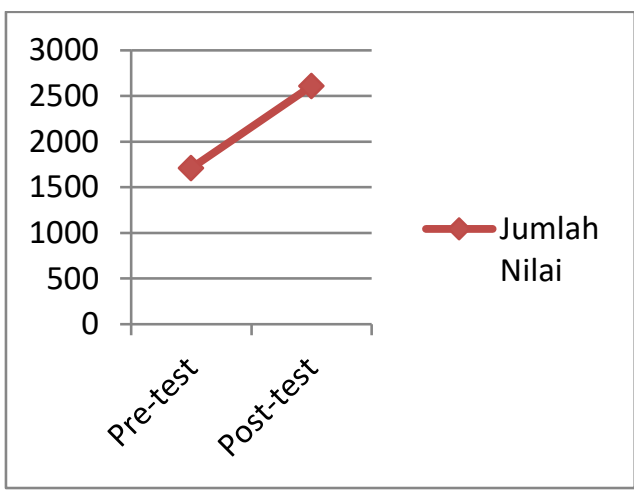

\section{Gambar 3. Grafik Keefektifan}

Penelitian ini juga serupa dengan penelitian (Lestari, Dewi, \& Ulia, 2020)yaitu test berupa soal pretest dan soal post-test digunakan sebagai teknik pengumpulan data, dimana bahan ajar You-MathBook efektif digunakan untuk pembelajaran dengan hasil Uji gain sebesar 0.35 pada kategori sedang.

\section{SIMPULAN}

Hasil penelitian dan pembahasan penelitian "Pengembangan BALING untuk Meningkatkan Prestasi Belajar Siswa Kelas VI SDN Sumbermulyo 01" 
Jurnal Riset Pendidikan Dasar

Volume 2 Nomor 2, September 2021; DOI 10.30595/jrpd.v2i2.9908

yang telah diuraikan dapat ditarik kesimpulan bahwa pengembangan bahan ajar BALING menggunakan model ADDIE, dinyatakan layak dari hasil uji validasi. Uji kepraktisan menunjukkan bahwa bahan ajar BALING 'praktis' digunkan dalam pembelajaran. Uji keefektifan menunjukkan adanya kenaikan nilai siswa sebesar 900 dengan menggunakan Uji Gain Ternormalisasi sebesar 0,69 pada kategori sedang. Jadi bahan ajar BALING 'efektif' meningkatkan prestasi belajar siswa meskpun dalam kategori sedang.

Saran

Berdasarkan penelitian yang telah dilakukan, peneliti menyampaikan beberapa saran untuk penelitian yang akan dilakukan selanjutnya:

1. Penggunaan bahan ajar BALING hendaknya didampingi oleh guru dan orang tua siswa, sebab bahan ajar ditunjang dengan penggunaan gadget.

2. Hasil pengembangan bahan ajar BALING dapat digunakan sebagai acuan dalam mengembangkan bahan ajar pada materi lain.

3. Produk BALING diharapkan dapat bermanfaan bagi guru, siswa, dan sekolah.

\section{DAFTAR PUSTAKA}

Jazuli, M., Azizah, L. F., \& Meita, N. M. (2017). Pengembangan Bahan Ajar Elektronik Berbasis Android Sebagai Media Interaktif. Jurnal Lensa (Lentera Sains), 7(20), 47-65.

Kususmadewi, R. F., Ulia, N., \& Sari, Y. (2020). Pengembangan Bahan Ajar Matematika Berbasis Komik Digital untuk Meningkatkan Minat Baca Siswa
SekolahDasar. Jurnal Phenomenon, 10(1), 85-101.

Lestari, I. P., Dewi, R. F. K., \& Ulia, N. (2020). Pengembangan You-Mathbook untuk Meningkatkan Pemahaman Konsep Perkalian Pada Siswa SD Islam Darul Huda Kota Semarang. Profesi Pendidikan Dasar, 7(1), 105-120.

Nugroho, R., \& Setyawati, R. T. (2016). Penggunaan Media Kancing Magnetik untuk Meningkatkan Kemampuan Berpikir Kritis Siswa Materi Perkalian Bilangan Bulat. Jurnal Pendidikan, 1(2), 183-189.

Prastowo, A., \& Wijaya, D. (2012). Panduan Kreatif Membuat Bahan Ajar Inovatif (4th ed.). Yogyakarta: Diva Press.

Saputra, henry J., \& Faizah, N. I. (2017). Pengembangan Bahan Ajar untuk Menumbuhkan Nilai Karakter Peduli Lingkungan Pada Siswa Kelas IV Sekolah Dasar. Profesi Pendidikan Dasar, $4(1), 62-74$.

Sari, Y. (2017). Pengembangan Bahan Ajar Komik IPA dengan Penanaman Nilai Budai pada Siswa Kelas IV Sekolah Dasar. JSPD, 3(2), 129-142.

Subaryana. (2015). Konsep Diri dan Prestasi Belajar. Jurnal Dinamika Pendidikan Dasar, 7(2), 21-30.

Sugiyono. (2017). Metode Penelitian Pendidikan. Bandung: Alfabeta.

Tegeh, I. M., \& Kirna, I. M. (2013). Pengembangan Bahan Ajar Metode Penelitian Pendidikan dengan ADDIE Model. Jurnal Ika, 2.

Ulia, N., Sari, Y., \& Hariyono, M. (2020). Pengaruh Bahan Ajar Konsep Dasar Matematika Berbasis Internalisasi Nilai-Nilai Islam Terhadap Sikap 
Jurnal Riset Pendidikan Dasar

Volume 2 Nomor 2, September 2021; DOI 10.30595/jrpd.v2i2.9908

Religius. Jurnal Studi Guru Dan

Pembelajaran, 3(1), 1-10. 